\title{
Development of Small and Medium Business in Tirana
}

\section{Bitila Shosha, PhD Candidate}

Lecturer, "Aleksander Moisiu" University, Business Faculty, Durres, Albania E-mail: bitilashosha@yahoo.com

\section{Doi:10.5901/mjss.2013.v4n13p699}

\section{Abstract}

This study is an overview of the current economic situation in the city of Tirana and reflects the facilities of doing business in the capital. The study deals with the economic development and analyses the economic reforms undertaken, taking into consideration the business favourable geographical position of Tirana. In terms of facilities of doing business, Tirana is ranked $5^{\text {th }}$ in the Balkans and in $86^{\text {th }}$ country in the world. This study refers to the National Registration Centre and its impact on facilitating business registration. It also analyses in detail the types of businesses in Tirana, classifying then into categories and activities. A survey on problems faced by the local companies and relevant recommendation are included to the stud. The survey on undertakings in Tirana serves as a tool for entrepreneurs to express their opinions on the quality of services offered by the Municipality. This survey was conducted by the Department of Economic Development, Business Facilitation Division and Statistics Division.

Keywords: SME; Department of Economic Development; Municipality of Tirana.

\section{Business Climate in Tirana}

\subsection{Businesses in Tirana as per their category}

The number of business entities in Tirana, during the four years has increased considerably from 21051 entities which operated in 2009 to 28416 operating business entities of nowadays. This increase comes as a consequence of economic development which has characterised Albanian in general the last years. This increase has effected not only on the increase of number of the business entities but also of them being legalized. The latter factor has brought a decrease of informality and it assures the fair competition in the market. A substantial increase of business entities has occurred from 2009 to 2012. During this period the number of entities operating in Tirana has increased 6018 entities.

Table 1: Business situation in Tirana over the years ${ }^{1}$

\begin{tabular}{cc}
\hline Businesses over the years & Total \\
\hline Year 2009 & 21051 \\
Year 2010 & 22398 \\
Year 2011 & 26683 \\
Year 2012 & 28416 \\
\hline
\end{tabular}

Chart 1: Development of business in Tirana

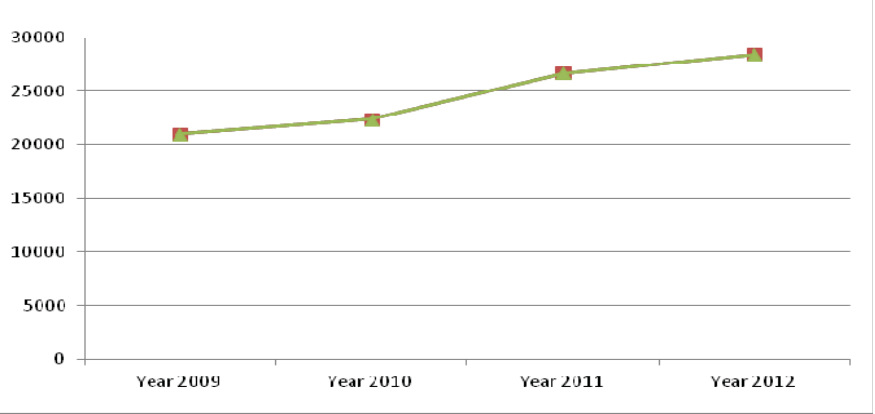

1 The data have been taken from the Statistics Sector of the Economic Development Directorate, Municipality of Tirana 
From the data we can ascertain that mainly small and medium business entities operate in Tirana. However, the number VIP business entities have been increased significantly. The category "other", which includes all those business entities of the service sector, such as legal offices, notary, dental clinics and artisanal services, etc., has, with the years, become higher.

Table 2: Situation of business in Tirana as per their categories ${ }^{2}$

$\begin{array}{ccccc}\text { Types of business over the years } & \text { Small businesses } & \text { Big businesses } & \text { VIPs } & \text { Others } \\ \text { Year 2009 } & 16,654 & 3,449 & 388 & 531 \\ \text { Year 2010 } & 17,759 & 3,640 & 413 & 607 \\ \text { Year 2011 } & 21,015 & 4,460 & 440 & 789 \\ \text { Year 2012 } & 22,266 & 4,814 & 584 & 834\end{array}$

Chart 2: Development of business as per their category

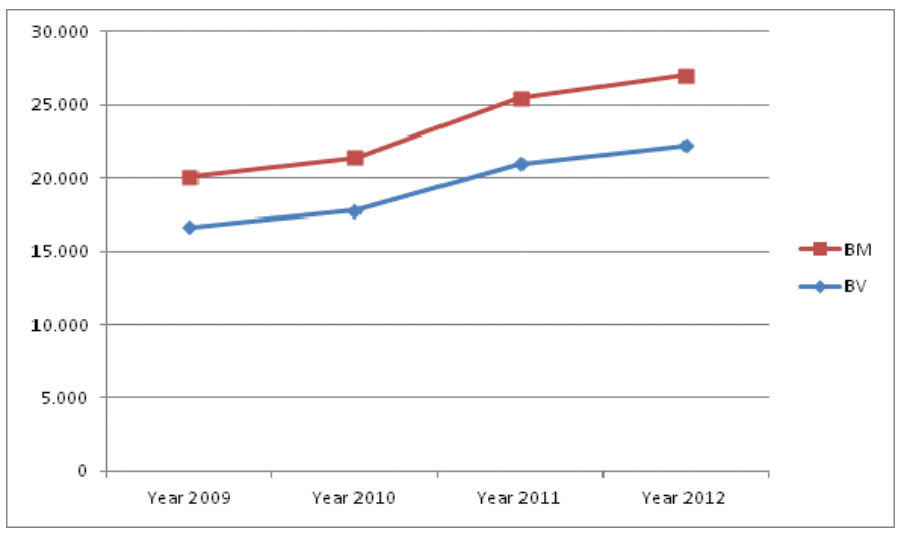

From the above chart we can see that the number of small and big business entities have become larger and larger. If we check the numbers of different years we can see that a considerable increase of business entities has taken place from 2009 up to 2012. Specifically, the difference is $1200-1400$ entities.

\subsection{Main sectors operating in Tirana}

\subsubsection{Business entities as per their activity ${ }^{3}$}

\begin{tabular}{lc}
\multicolumn{1}{c}{ Business as per their sector } & Total \\
Production entities & 2435 \\
Service entities & 5751 \\
Retail & 7037 \\
Wholesale & 4427 \\
Transport & 1018 \\
Construction & 2483 \\
Free-lancers & 2602 \\
Bookshops and publishing houses & 326 \\
Art Galleries & 62 \\
Foundations, Associations & 677 \\
Pharmaceutical production & 444 \\
Bar-Restaurant, Fast-Food & 4677 \\
Hotels & 2815 \\
Internet-café and Casino & 1031
\end{tabular}

\footnotetext{
2 The data have been taken from the Statistics Sector of the Economic Development Directorate, Municipality of Tirana

3 The data have been taken from the Local Tax and Tariffs General Directorate, Municipality of Tirana.
} 


$\begin{array}{lc}\text { Sport Complexes } & 97 \\ \text { Second tiers banks } & 27 \\ \text { Street merchants } & 3023 \\ \text { Others (licensed entities) } & 26\end{array}$

Chart 3: Business in Tirana as per their sector

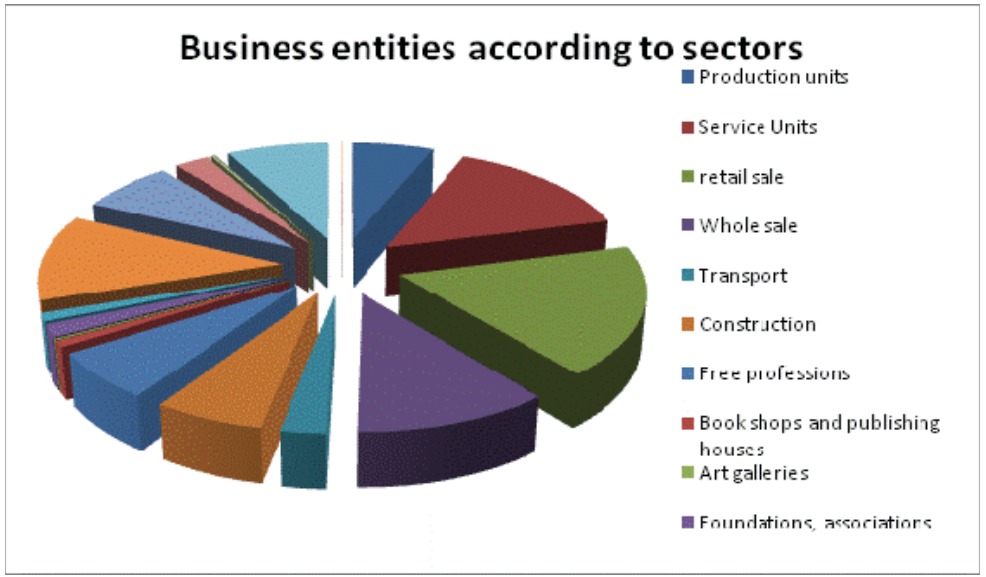

Based on the composing structures of the business entities, according to their type of activity, we can see:

- the first place continues to be occupied by the retail sale business entities which are 7037 entities.

- the second place is occupied by the service sector business entities with 5751 entities.

- $\quad$ the third place is occupied by leisure activities (Bars-Restaurants) with 4677 entities.

- while production is ranked in the fourth place.

As a result, we can assume that Tirana has a positive business climate for establishing new business entities. The National Registration Centre has made it easier and simpler to get registered and follow the licensing procedure. The city of Tirana continues to promote its image as an important metropolitan centre in the Balkans and as a favourite place for making investments.

\subsection{Construction ${ }^{4}$}

Tirana is the main city for the industry of construction in Albania. The construction rate is 10 times higher than in any other town. There are about 676 construction companies which consist in $80 \%$ of all construction companies in the country. The largest share of percentage is civil construction, which has $60 \%$. The big development of this sector has caused opening of many production enterprises in this sector, specifically 612 business entities are producing construction materials which consists in $2.5 \%$ of the producing enterprises in Tirana.

According to the latest World Bank report ${ }^{5}$, Albania is ranked 170 from 181 countries considered in the survey. The survey lasted 331 days. There are 24 procedures to be provided with a building permit. Albania takes the first country in the region in terms of cost which is $435 \%$ of the income per capita.

\subsection{Financial Sector}

Competition in the banking sector is growing continuously. Notwithstanding the fact that banks has a high profit, they continue to expand the number of products they provide such as debit and credit cards, Visa cards, sale of bonds, expanding the loan portfolio, etc. In addition, they continue to enlarge the number of branches in Tirana and in the districts.

\footnotetext{
4 The data has been taken from the Local Tax and Tariffs General Directorate, Municipality of Tirana

5 Taken from the "Making Business 2009" report
} 


\subsection{Tourism}

Tourism in Tirana has experienced a real qualitative and quantitative boom. There is a raise of the hotels' quality. Here it is worth mentioning the opening of hotels with 4 and 5 stars compared to those of European countries.

\subsection{Tirana as a business centre and the city of commercial centres}

Tirana is the capital of Albania. It has the greatest purchasing power in the country. Currently there are 8 shopping centres in Tirana. About $90 \%$ of foreigners settled in Tirana visit these shopping centres. Approximately all economic and socio-cultural, national and international business affairs, sports and cultural activities are done in Tirana. It offers structure capacity of 2800 seats for organizing national and international conferences.

\section{A Survey on the Business in the City Of Tirana}

\subsection{Content and Structure}

The survey was conducted for a period of one month. It engaged a team of interviewers who conducted field interviews in the city of Tirana. The questionnaire comprised questions as follows:

- Which are the three biggest obstacles that enterprises are facing today?

- Which is the impact of generated by the tax system applied by the Local Tax and Tariffs Directorate General?

- Which is the role of the Municipality in improving the business climate?

\subsection{Instrument used and data collected}

The instrument used for the conduction of this survey was the questionnaire designed in the form of direct interview lasting for 10 minutes. The major categories of variables measured were:

a. Opinions on the quality of public services provided by the Municipality;

b. Opinions on the relationship between the enterprises and municipal offices;

c. Opinions on the quality and the needs for direct and indirect services provided by the Municipality to the enterprises.

\subsection{Ethics of observation}

The ethics of research was observed in any aspect of the survey taking into consideration the consent of entrepreneurs and confidentiality of the data, thus guaranteeing professionalism and objectivity in the stage of data collection.

\subsection{Local enterprises concerns}

a. Competition

- The majority of enterprises surveyed consider that the city of Tirana is a good favourable place to make business, taking in consideration here all the relevant factors: total cost of doing business, social factors and new and qualified labour force.

- The majority of business entities surveyed think that they are competitive in the market and have a consolidated activity of over 5 years of standing.

- In general, respondents consider that the quality of life in Tirana is good and it helps them in selling products and providing information.

b. A general economic observation

- The economic context of this survey is accompanied by a low optimism, and influenced by the economic crisis that is facing the world economy.

- The majority of respondents said that their business has served for self-employment and also for the employment more than 5 employees.

- A low percentage of businesses respondents said that they had plans to increase their activity and this increase was to take place within the city.

c. How much informed is the local business? 
- The majority of respondents said they are not aware of any business association that can help them in their work.

- The majority of respondents said they were not aware of the existence of any structure within the Municipality which can help or give directions to the development of their economic activity.

d. What is business looking for?

- About $49 \%$ of respondents said that public services are an obstacle in the development of their economic activity. They asked for better public cleaning services, infrastructure improvement, more parking areas near business activities so that it is easier for customers to stop at their premises.

- Most businesses respondents said that they pay taxes regularly and have no difficulty in paying them. However, they anxious from being frequently inspected by the local tax inspectors.

\section{Conclusions}

The obstacles faced nowadays by local small enterprises are:

1. Unfair and informal competition:

- street merchants are working without license and they do not pay taxes;

- discrepancy in pricing products or services.

2. Inadequate level of public services, which is barrier to business performance, mainly:

- lack of parking places

- high level of pollution

- lack of green spaces, etc.

3. Lack of infrastructure, such as unpaved sidewalks.

4. Opening of same businesses within a certain area without planning.

5. Lack of training for the employees which affects negatively on business performance.

6. Lack of advanced technology (backward technology).

In addition, the tax policies imposed by the Local Tax and Tariffs General Directorate are another significant concern for small entrepreneurs.

During the course of this survey, some issues which affect adversely on the business entities were identified. They are:

1. The high value of the tax rate is a very serious problem since the development of businesses has not been considerable.

2. Besides this concern, enterprises are overburdened with excessive controls of the Local Tax and Tariffs General Directorate inspectors, who carry out over 5 checks a year.

3. There is disparity in tax value for the entities of the same categories.

4. Imposing taxes from the initial days of business operation impedes the young entrepreneurs.

During the controls of the Local Tax and Tariffs General Directorate inspectors carried out in 100 business entities, which were covered by the survey, there were ascertained many irregularities, therefore fines were imposed.

The reasons of the fines were:

- Default in paying taxes on time;

- Non declaration of employees

- Placing ornaments on the facade;

- Non declaration of annual turnover;

\section{Recommendations}

Based on the current situation, different recommendations can be issued for the local administration. Some of them are:

1. Conducting a study on fiscal policies that are currently applicable on businesses, in order to identify incentives.

This study should take into account:

- Change of the tax rate, depending on the location of the business entity;

- Equity in taxation among similar businesses entities;

- Drafting of policies for the simplification of permits and licenses;

- Application of a different tax system for business entities that are currently starting their activity. 
2. Drafting a plan to localize the business entities distribution.

3. The respective municipal bodies should take the following measures:

- close non-licensed businesses;

- improve public services;

- inform entrepreneurs on business taxation policies;

- review the license terms of public transport;

- promote business supporting services;

- drafting a business control plan, with the participation of municipal bodies;

- guaranteeing fair competition in the market;

- guaranteeing protection of consumers;

- simplify the permit and license procedures and limit the business inspection controls;

- improve business climate.

\section{References}

Statistics Department, Economic Development Directorate, Municipality of Tirana;

Local Taxes and Tariffs General Directorate, Municipality of Tirana;

Regional Employment Office, Tirana;

World Bank reports on small and medium enterprises:

Albania at a Glance, 2010

Doing business in Albania, 2010

INSTAT: Results on the Structural Survey of Enterprises 2007-2009. INSTAT, Economic Register of Enterprises;

Ministry of Economy, Trade and energy (2005, 2009): Annual Reports of the Ministry of Economy;

Ministry of Economy, Trade and energy: Centre for research and development. Observatory of SMEs in Albania.

Ministry of Economy, Trade and energy: Medium term strategy for the development of small and medium enterprises (2007-2013);

Timmons Jefri A., (2004) How to Raise Capita / ... (Techniques and Strategies for Financing your small business);

The ultimate small business guide, a resource for start-up and Growing Businesses. 